\title{
Inventarisasi Jenis dan Distribusi Habitat Rotan pada Hutan Dataran Tinggi dan Dataran Rendah di Kalimantan Selatan
}

\author{
Inventory and Habitat Distribution of Rattans on Upland and Lowland Forest in South \\ Kalimantan
}

\section{Yudi Firmanul Arifin}

Fakultas Kehutanan Universitas Lambung Mangkurat, Jl. A. Yani Km 36 Banjarbaru, Kalimantan Selatan E-mail: yudifirmanul@yahoo.com

\begin{abstract}
Rattans are spiny climbing palms in the Old World tropics and subtropics. Some species are the source of cane for the cane furniture industry in Indonesia. The large number of rattan species and their wide geographical range is matched by great ecological diversity. The restriction of rattan species to different climatic zones and altitudinal range suggests that these species may have precise climatic requirements and also altitudes. The research was conducted on upland and lowland of natural forest in South Kalimantan. The data collection used survey with transect method. Volume of rattans in upland forest was relatively lower than lowland forest. In altitudinal range in South Kalimantan, rattans were found from sea-level up to $870 \mathrm{~m}$, the highest altitude record being held by Calamus javensis, Daemonorops micracantha, Calamus pilocellus, and Calamus sp. (rotan tunggal). While the lowest altitude record was occupied by Calamus trachycoleus. Rattans in natural forest require light intensity, humidity and temperature were $18-65 \%, 60-70 \%, 28-33^{\circ} \mathrm{C}$, respectively.
\end{abstract}

Key words: rattan, diversity, forest, altitude, climatic

Diterima: 04 Maret 2008, disetujui: 02 Juni 2008

\section{Pendahuluan}

Hingga kini kebutuhan bahan baku rotan komersial, baik untuk industri kecil maupun besar di Indonesia, khususnya di Kalimantan terus meningkat, untuk kelangsungan industri tersebut tentu saja membutuhkan sumber bahan baku yang besar dan terus menerus. Akan tetapi hutan alam yang menjadi habitat rotan dari tahun ketahun terus mengalami degradasi, baik akibat penebangan pohon-pohon untuk konsumsi industri perkayuan maupun pembukaan areal untuk pemukiman penduduk, pertambangan, serta kebutuhan lain. Aktivitas ini tentu saja sangat besar sekali pengaruhnya secara ekologis terhadap populasi rotan di alam tersebut. Dilain pihak budidaya rotan masih dalam skala kecil dan belum dapat memenuhi kebutuhan untuk skala besar. Budidaya rotan hanya terbatas pada jenis-jenis tertentu yang dikenal bernilai ekonomis atau dibutuhkan oleh industri, seperti rotan sega (Calamus caesius) dan rotan irit (Calamus trachycoleus). Jenisjenis lainnya yang belum dikenal oleh masyarakat atau pasar belum dilakukan pembudidayaan, sehingga upaya preventif dalam rangka pembudidayaan dan pelestarian rotan lainnya perlu dilakukan. Salah satu upaya untuk menunjang budidaya rotan adalah mengetahui keanekaragaman, distribusi dan habitat dari masing-masing jenis rotan di hutan alam (Arifin, 2003)

Hingga kini penelitian rotan di habitat alam masih sangat terbatas terutama penelitian dari aspek ekologi dan budidaya sehingga menyebabkan rendahnya perhatian terhadap kelestarian rotan alam tersebut (Arifin, 2003) 
Tujuan penelitian ini adalah untuk mengetahui jenis dan distribusi habitat rotan alam pada hutan dataran tinggi dan dataran rendah, serta memetakan sebaran tumbuhan tersebut. Diharapkan data dan informasi yang terkumpul dapat menjadi pertimbangan untuk pembudidayaan dan konservasi rotan di habitat alam. Jenis-jenis rotan di habitat alam ini keberadaannya sudah mulai langka, tetapi kebutuhan industri terus meningkat sehingga untuk mengurangi ancaman kepunahan sangat dibutuhkan upaya pembudidayaan.

\section{Metode Penelitian}

\begin{abstract}
Penelitian dilaksanakan di Kalimantan Selatan, dengan pengambilan sampel di Kabupaten Hulu Sungai Selatan dan Kabupaten Barito Kuala. Kedua kabupaten ini paling potensial ditinjau dari luas kawasan hutan dan produksi rotannya. Penempatan sampel didasarkan informasi dari masyarakat setempat yang mengetahui keberadaan rotan di hutan alam (Arifin et al., 2006).
\end{abstract}

\section{Inventarisasi}

Pengamatan rotan dilakukan di hutan primer dan hutan sekunder di Kabupaten Hulu Sungai Selatan dan Kabupaten Barito Kuala Provinsi Kalimantan Selatan. Pengamatan diawali dengan peninjauan ke lokasi hutan alam, tempat yang diduga sebagai habitat rotan berdasarkan laporan-laporan serta informasi dari masyarakat lokal.

Pengumpulan data lapangan dilakukan dengan membuat transek pada lokasi-lokasi yang terdapat populasi rotan. Masing-masing transek berukuran $20 \times 1000 \mathrm{~m}$. Pada setiap transek dibuat petak pengamatan berukuran 20 x 20 m secara terus menerus. Pada setiap petak dilakukan pengamatan semua spesies tumbuhan rotan, dilakukan perhitungan jumlah rumpun bagi jenis rotan yang berumpun dan jumlah batang bagi rotan tunggal (solitary species). Pada setiap transek yang terdapat rotan juga dilakukan pengukuran ketinggian dari permukaan laut, intensitas cahaya, kelembaban dan suhu udara, untuk menjelaskan kondisi habitat rotan di alam. Pengukuran intensitas cahaya, kelembaban dan suhu udara dilakukan pada sekitar pukul 10.00
- 12.00 Wita. Dari hasil ini diperoleh jenis, potensi, dan keadaan iklim mikro yang dibutuhkan oleh masing-masing spesies dan ketinggian tempat ditemukan rotan.

Untuk mendapatkan nama botanis rotan yang diperoleh, dilakukan dengan identifikasi langsung di lapangan untuk jenis-jenis yang sudah dikenal, sedangkan jenis-jenis yang belum dikenal dilakukan dengan pengambilan spesimen, selanjutnya dilakukan identifikasi di Lab. silvikultur Fakultas Kehutanan Unlam.

\section{Memetakan penyebaran tumbuhan rotan}

Metode yang digunakan dalam memetakan habitat rotan dari hutan dilakukan dengan jalan menentukan koordinat ditemukannya jenis-jenis rotan tersebut baik pada wilayah dataran tinggi maupun dataran rendah. Hasil survei penyebaran rotan alam tersebut dipetakan, sehingga diketahui distribusi jenis-jenis rotan tersebut di alam (Arifin et al., 2006).

\section{Hasil dan Pembahasan}

\section{Jenis dan habitat rotan dataran tinggi di Kabupaten Hulu Sungai Selatan}

Berdasarkan hasil penelitian di kawasan Pegunungan Meratus, Kecamatan Loksado Kabupaten Hulu Sungai Selatan diperoleh 15 spesies rotan tergolong dalam 3 genus. Setiap spesies sebagian besar hidup mengelompok di dekat aliran sungai pada ketinggian tempat yang berbeda-beda antara $462 \mathrm{~m}$ - $870 \mathrm{~m}$ dari permukaan laut. Secara rinci spesies-spesies yang ditemukan di daerah ini dapat dilihat pada Tabel 1.

Ditinjau dari aspek potensi rotan yang berada di hutan alam sudah sangat rendah, hal ini disebabkan semakin terdegradasinya hutan alam yang menjadi habitatnya. Rotan merupakan hasil hutan ikutan yang hidupnya sangat tergantung pada keberadaan hutan. Kondisi iklim mikro dan pohon inang untuk rambatan yang tersedia sangat menentukan keberadaan rotan di habitat alam (Arifin, 2003). Pertumbuhan optimal semai rotan memerlukan cahaya 50\% (Mori, 1980), intensitas cahaya di lokasi studi bervariasi antara $18 \%$ - 65\% dengan tegakan yang sebagian masih rapat. 
Pada lokasi hutan alam yang sudah sangat jarang tidak ditemukan rotan. Setiap jenis rotan memerlukan intensitas cahaya yang bervariasi antara 30 - 80\% (Burnette et al., 2006). Dari hasil survei diketahui bahwa hanya dua spesies yang penyebarannya cukup merata, yaitu rotan siit (Daemonorops monticola) dan rotan gatah (Daemonorops melanocaetes). Kedua jenis ini hidup pada ketinggian $462 \mathrm{~m}$ dpl. Sedangkan jenis-jenis yang dapat hidup pada ketinggian bervariasi dari rendah hingga tinggi adalah rotan lilin (Calamus javensis) dan rotan taman (Calamus caesius), masing-masing 462 - 870 m dpl dan 462 - 812 m dpl. Dari hasil penelitian ini menunjukkan bahwa ketinggian tempat sangat mempengaruhi penyebaran rotan.

Ditemukan hanya dua jenis rotan yang sudah bernilai komersial atau banyak diperdagangkan, yaitu rotan taman (Calamus caesius) dan rotan manau (Calamus manan). Akan tetapi kedua jenis tersebut sudah sangat jarang ditemukan di hutan alam, sehingga perlu dilakukan pembudidayaan dan konservasi (Tabel 1). Pemanenan yang berlebihan di hutan alam dikhawatirkan akan menyebabkan kepunahan dua jenis rotan tersebut.

Secara umum penyebaran rotan di habitat alam terutama dijumpai pada lokasi yang berdekatan dengan aliran sungai dalam kawasan hutan. Hal ini karena daerah tersebut relatif lembab dan ketersediaan air yang cukup untuk hidupnya sepanjang tahun.

Pohon inang yang sangat diperlukan oleh rotan sebagai tempat menopang untuk memperoleh cahaya adalah pohon-pohon yang memiliki batang agak kasar, percabangan rendah dan batang yang kokoh (Arifin, 1995; Arifin, 2003). Jenis-jenis ini banyak ditemukan di tepi sungai seperti: alaban (Vitex pubescens), bungur (Lagerstromia speciosa) dan lain-lain.

\section{Penyebaran spesies di dataran tinggi Kabupaten Hulu Sungai Selatan}

Dari hasil survei yang telah dilakukan menunjukkan bahwa rotan alam pada kawasan hutan yang terdapat di Kabupaten Hulu Sungai Selatan terbanyak ditemukan pada ketinggian antara 462 - 870 m dari permukaan laut. Di Vietnam rotan sangat cocok hidup pada ketinggian 500 - $550 \mathrm{~m}$ dpl (Ban et al., 2005). Menurut Dransfield (2001), rotan dapat hidup hingga ketinggian $3.000 \mathrm{~m}$ dpl. Secara umum tumbuhan rotan alam tumbuh mengelompok dan tersebar di sekitar anak-anak sungai. Kelembaban yang cocok bagi rotan antara $60 \%$ - $70 \%$, dengan suhu antara $28-32^{\circ} \mathrm{C}$ dan intensitas cahaya $24 \%$ - 65\%. Banyak jenis rotan memerlukan intensitas cahaya antara 30 80\% (Yin et al., 2000).

Tabel 1. Jenis-jenis rotan yang ditemukan, potensi dan faktor lingkungannya.

\begin{tabular}{lllccccc}
\hline \hline No & Nama Botanis & Nama Lokal & $\begin{array}{c}\text { Jumlah } \\
\text { Rumpun }\end{array}$ & $\begin{array}{c}\text { Ketinggian } \\
\text { Tempat } \\
(\mathbf{m} \text { dpl) }\end{array}$ & $\begin{array}{c}\text { Intensitas } \\
\text { Cahaya } \\
(\text { Lux })\end{array}$ & $\begin{array}{c}\text { Kelem- } \\
\text { baban } \\
(\mathbf{\%})\end{array}$ & $\begin{array}{c}\text { Suhu } \\
\text { Udara } \\
\left(\mathbf{(}^{\mathbf{} C)}\right.\end{array}$ \\
\hline \hline 1 & Daemonorops monticola & Rotan Siit & 34 & 462 & $27-65$ & 68 & 29 \\
2 & Calamus scipionum & Rotan Tuu & 1 & 462 & 65 & 61 & 32 \\
3 & Daemonorops melanocaetes & Rotan Gatah & 30 & 462 & 18 & 65 & 30 \\
4 & Calamus javensis & Rotan Lilin & 2 & $462-870$ & 18 & 65 & 30 \\
5 & Calamus mannan *) & Rotan Manau & 2 btng & 462 & 59 & 61 & 32 \\
6 & Calamus caesius & Rotan Taman & 4 & $462-812$ & 65 & 61 & 32 \\
7 & Korthalsia scaphigera & Rotan Huyi & 12 & 475 & 64 & 60 & 30 \\
8 & Korthalsia sp. & Rotan Baras & 1 & 475 & 64 & 60 & 30 \\
9 & Calamus sp. & Rotan Minung & 1 & 462 & 58 & 61 & 32 \\
10 & Korthalsia sp. & Rotan Wariung & 1 & 740 & 24 & 64 & 30 \\
11 & Daemonorops micracantha & Rotan Jerenang & 1 & $856-870$ & 24 & 70 & 28 \\
12 & Daemonorops oligophylla & Rotan Bambulau & 2 & 856 & 24 & 70 & 28 \\
13 & Belum teridentifikasi & Rotan Lantau & 1 & 870 & 24 & 70 & 28 \\
14 & Calamus sp. *) & Rotan Tunggal & 1 btng & 870 & 24 & 70 & 28 \\
15 & Calamus pilosellus & Rotan Paku & 1 & 870 & 24 & 70 & 28 \\
\hline \hline
\end{tabular}

Keterangan: *) Solitary species (jenis rotan yang tidak berumpun). 
Gambar 1 menunjukan penyebaran tumbuhan rotan pada hutan dataran tinggi di Kabupaten Hulu Sungai Selatan. Distribusi rotan pada hutan alam di Kabupaten Hulu Sungai Selatan terutama terdapat di Pegunungan Meratus yang belum mengalami degradasi yang sangat serius, sedangkan pada kawasan hutan yang sudah terbuka tidak ditemukan lagi tumbuhan rotan tersebut.

\section{Jenis dan habitat rotan dataran rendah di Kabupaten Barito Kuala}

Pada daerah alluvial dan rawa umumnya ditumbuhi oleh jenis rotan irit (Calamus tracycoleus). Jenis ini tumbuh sangat cepat dan mendominasi pada kawasan ini, seperti terjadi di Kabupaten Barito Kuala. Pada daerah ini jenis rotan ini tumbuh di sepanjang Sungai Barito dengan potensi yang sangat tinggi. Sangat sedikit jenis yang mampu hidup pada daerah alluvial ini. Rotan irit yang hidup di sini merupakan rotan yang dibudidayakan oleh masyarakat setempat, sehingga keberadaannya cukup terjaga dan sewaktu-waktu seandainya ada pembeli, pemiliknya akan memanen. Rotan irit memiliki selantar yang panjang, merayap di atas tanah. Selantar tersebut dapat tumbuh mencapai $25 \mathrm{~m}$ atau lebih pada rumpun yang sudah berumur 30 - 40 tahun. Jika selantar tersebut tergenang air, maka pada bukubukunya akan tumbuh akar nafas. Bersamaan dengan pertumbuhan akar nafas, tumbuh pula tunas yang menjadi batang pada setiap buku selantar. Dengan adanya selantar ini maka pertumbuhan rumpun tidak rapat. Sebaliknya rotan taman yang tidak mempunyai selantar maka rumpunnya akan rapat.

Perbedaan bentuk rumpun di antara jenis rotan akan mempengaruhi habitat, pemeliharaan dan pemanenannya. Rotan yang mempunyai selantar lebih tahan terhadap genangan air. Selain itu karena rumpunnya tidak terlalu rapat maka pemanenannya akan lebih mudah. Sebaliknya rotan yang tidak memiliki selantar hanya beberapa yang dapat hidup pada daerah pasang surut. Rotan taman salah satu spesies yang tidak berselantar, tapi dapat hidup pada daerah alluvial yang terkadang tergenang oleh air.

\section{Penyebaran spesies rotan di dataran rendah tanah alluvial di Kabupaten Barito Kuala}

Dari hasil survei yang telah dilakukan menunjukkan bahwa distribusi rotan terbanyak di Kabupaten Barito Kuala berada di pesisir sungai pada tanah alluvial. Jenis yang sangat dominan adalah rotan irit (Calamus trachycoleus) yang menyebar merata di pesisir sungai (Gambar 2). Rotan irit sangat cocok hidup di tanah alluvial dan tanah rawa (Mohammad, 1984). Rotan ini hidup pada ketinggian antara $10-17 \mathrm{~m}$ dari permukaan laut, dengan kelembaban $58 \%$, suhu $33^{\circ} \mathrm{C}$ dan intensitas cahaya $71 \%$. Distribusi rotan irit disajikan dalam Gambar 2.

Ditinjau dari potensi rotan yang terdapat di hutan alam Kalimantan Selatan sudah sangat jarang, hal ini dilihat dari jumlah rumpun pada masing-masing jenis yang sangat sedikit, terutama pada hutan dataran tinggi. Penyebab utamanya adalah semakin banyaknya kawasan hutan alam yang sudah mengalami degradasi. Areal hutan yang sudah terbuka sulit bagi rotan untuk hidup, walaupun beberapa jenis rotan mampu hidup dengan intensitas cahaya yang sangat ekstrem tinggi (Sunderland, 2001; Siebert, 2001). Namun biasanya rotan hidup di bawah tegakan yang masih memungkinkan penetrasi cahaya masuk (Arifin, 2003; Dransfield, 2001).

Pada hutan dataran rendah yang berada di pesisir sungai ditemukan hanya satu jenis, yaitu Calamus trachycoleus. Jenis ini sangat cocok hidup pada jenis tanah alluvial pada ketinggian 10 - 17 m dpl. Calamus trachycoleus memiliki selantar yang panjang (stolon) dan akan terjadi penambahan batang yang sangat cepat pada setiap selantarnya, sehingga batang yang dihasilkan sangat banyak dan rapat (Razak et al., 2001). Jenis ini termasuk jenis komersial yang dibutuhkan oleh industri (Arifin, 1995).

Rotan taman (Calamus caesius) dan rotan manau (Calamus manan) merupakan dua jenis rotan yang sangat komersial dan dibutuhkan oleh industri (Belcher, 2001), akan tetapi potensinya sudah sangat jarang (Tabel 1), sehingga upaya budidaya kedua jenis ini sangat diperlukan. Rotan taman adalah jenis rotan berdiameter kecil $<18 \mathrm{~mm}$ yang dapat hidup 
pada dataran rendah tanah alluvial, rawa hingga dataran tinggi $800 \mathrm{~m}$ dpl. (Razak et al., 2001). Sedangkan rotan manau merupakan rotan tunggal (solitary species) yang termasuk rotan berdiameter besar $>18 \mathrm{~mm}$ dan hidupnya pada hutan dipterocarpaceae pada ketinggian antara 600 - 1000 m dpl (Arifin, 1995; Razak et al., 2001; Arifin, 2003).

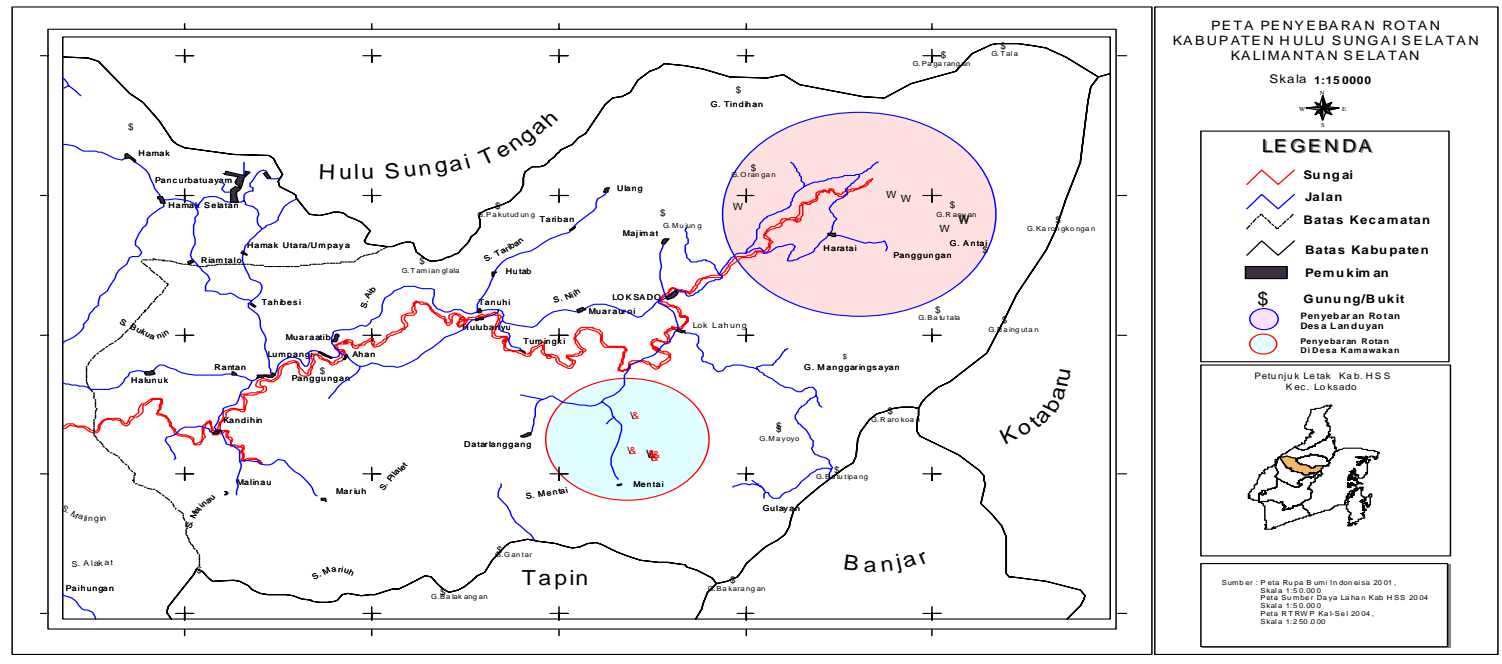

Gambar 1. Peta penyebaran rotan di Kec. Loksado (Pegunungan Meratus), Kab. Hulu Sungai Selatan. Keterangan: $\bigcirc$ : Distribusi rotan di hutan alam dataran tinggi Pegunungan Meratus.

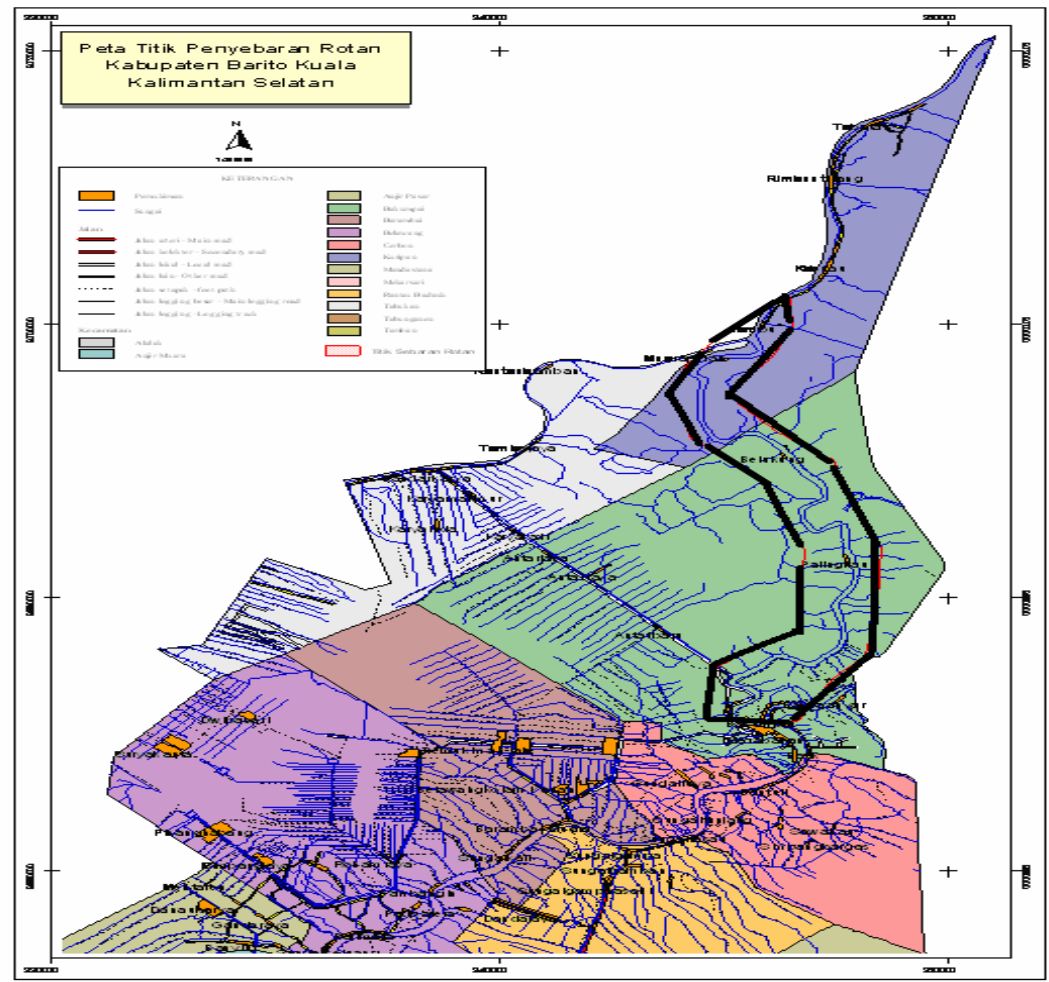

Gambar 2. Peta penyebaran rotan di dataran rendah (tanah alluvial) pesisir Sungai Barito di Kab. Barito Kuala.

Keterangan: Distribusi rotan di hutan alam dataran rendah (pesisir Sungai Barito). 


\section{Kesimpulan}

Dari hasil penelitian ini dapat disimpulkan bahwa: potensi rotan di habitat hutan alam sudah sangat jarang, terutama pada kawasan hutan alam dataran tinggi. Sedangkan pada hutan dataran rendah $10-17 \mathrm{~m}$ dpl potensi rotan tinggi, akan tetapi jumlah jenis sangat sedikit. Penyebaran rotan di hutan alam sangat bervariasi tergantung pada ketinggian tempat dari permukaan laut. Jenis rotan pada dataran tinggi ditemukan pada ketinggian antara 462 - $870 \mathrm{~m} \mathrm{dpl}$, dengan intensitas cahaya bervariasi antara $18-65 \%$, kelembaban $60-70 \%$ dan suhu udara $28-32^{\circ} \mathrm{C}$. Pada lokasi dataran rendah ditemukan hanya satu jenis spesies dominan yaitu rotan irit (Calamus trachycoleus). Jenis ini ditemukan pada ketinggian antara $10-17 \mathrm{~m}$ dpl, dengan intensitas cahaya $71 \%$, kelembaban $58 \%$ dan suhu udara $33^{\circ} \mathrm{C}$.

\section{Daftar Pustaka}

Arifin, Y.F. 1995. The Rattan Gardens in North Barito District; A Case Study in Muara Tupuh Village, Central Kalimantan. Thesis for the degree "Master of Tropical Forestry" in Faculty of Forestry Science, Georg-August University, Göttingen.

Arifin, Y.F. 2003. Traditionelle Rattangärten in Zentralkalimantan, Indonesien. Dissertation zur Erlangung des Doktorgrades der Fakultät für Forstwissenschaften und Waldökologie der Georg-August-Universität Göttingen, Deutschland.

Arifin, Y.F., Aqla, M. dan Edila, Y.P. 2006. Tumbuhan Berkhasiat Obat dari Hutan di Kabupaten Hulu Sungai Selatan Kalimantan Selatan. J. Agroscientiae 13 (1): 1-10.

Ban, N.K., Regalado, J., Hung, N.P., Dung, N.Q., Binh, B.M. and Anh, T.H. 2005. Rattan Resource of Bach Ma National Park, Thua Hue Province. Agricultural Review No. 14/2005. Tropenbos International Vietnam Programme.
Belcher, B. 2001. Rattan cultivation and livelihoods: the changing scenario in Kalimantan. An international journal of forestry and forest industries Vol. 52- 2001/2 FAO - Food and Agriculture Organization of the United Nations.

Burnette, R. and Morikawa, B. 2006. Rattan Seed Germination and Storage Study in Northern Thailand. Uplands Holistic Development Project (UHDP). Fang, Chiang Mai 50110 Thailand.

Dransfield, J. 2001. Taxonomy, Biology and Ecology of Rattan. An International Journal of Forestry and Forest Industries Vol. 52- 2001/2 FAO Food and Agriculture Organization of the United Nations.

Mohammad, A. 1984. Performances of Some Rattan Species in Growth Trials in Peninsular Malaysia. Proceedings of Rattan Seminar in Kuala Lumpur, Malaysia. Proceedings of Rattan Seminar in Kuala Lumpur, Malaysia.

Mori, T. 1980. Growth of Rotan Manau (Calamus manan) Seedling Under Various Light Conditions. Malay. For. 43: 187-191.

Razak, A.M.A. and Raja, B.R.S. 2001. Intercropping Rattan with Rubber and Other Crops. An International Journal of Forestry and Forest Industries Vol. 52- 2001/2 FAO - Food and Agriculture Organization of the United Nations.

Siebert, S.F. 2001. Sustainable Harvesting of Wild Rattan: Viable Concept or Ecological Oxymoron?. An International Journal of Forestry and Forest Industries Vol. 52- 2001/2 FAO - Food and Agriculture Organization of the United Nations.

Sunderland, T.C.H. 2001. Rattan Resources and Use in West and Central Africa. An International Journal of Forestry and Forest Industries Vol. 52- 2001/2 FAO - Food and Agriculture Organization of the United Nations.

Yin, G.T., Xu, H.C., Zhang, W.L., Fu, J.G. and Zeng, B.S. 2000. Cultivation of Rattan Species. Research on Rattan in China, Conservation, Cultivation, Distribution, Ecology, Growth, Phenology, Silviculture, Systematic Anatomy and Tissue Culture. IPGRI-APO, Serdang, Malaysia. 